\title{
C. Wright Mills Through his Letters - His Time in Innsbruck and the Making of The Sociological Imagination
}

Kathryn Mills

kate.mills301@gmail.com

\begin{abstract}
In June 1957, C. Wright Mills came to Innsbruck, Austria, by VW Bus with his wife at the time, Ruth Harper Mills, and their daughter, Kathryn. Wright Mills had just completed a year as Fulbright lecturer at the University of Copenhagen. In this article, based on a presentation at the University of Innsbruck, Kathryn Mills discusses her father's experiences in Austria, his work on The Sociological Imagination, her family's personal crises in Innsbruck, and her father's writings on personal trouble and engagement with big issues. The article features quotations from C. Wright Mills: Letters and Autobiographical Writings and a passage from The Sociological Imagination.
\end{abstract}

\section{Keywords}

C. Wright Mills, The Sociological Imagination, personal troubles, political issues, internationalism of intellectual life

\section{Wright Mills durch seine Briefe - seine Zeit in Innsbruck und die Entstehung von Soziologische Phantasie}

\section{Zusammenfassung}

Im Juni 1957 kam C. Wright Mills mit einem VW Bus mit seiner damaligen Frau, Ruth Harper Mills, und deren Tochter, Kathryn, nach Innsbruck, Österreich. Wright Mills hatte gerade ein Jahr als Fulbright Lecturer an der Universität von Kopenhagen absolviert. In diesem auf einer Präsentation an der Universität Innsbruck basierenden Artikel erörtert Kathryn Mills die Erfahrungen ihres Vaters in Österreich, seine Arbeit an The Sociological Imagination, die persönliche Krise ihrer Familie in Innsbruck, sowie die privaten Aufzeichnungen über persönliche Probleme und sein Engagement für wichtige Themen. Der Artikel beinhaltet Zitate aus C. Wright Mills: Letters and Autobiographical Writings und einen Ausschnitt aus Soziologische Phantasie.

\section{Schlüsselwörter}

C. Wright Mills, Soziologische Phantasie, persönliche Probleme, politische Themen, Internationalismus des intellektuellen Lebens

The author has declared that no competing interests exist.

Copyright (C) 2018 by Kathryn Mills 
Ich spreche kein Deutsch. When I was a small child, I could speak German, but no more. I hope you'll excuse my English today.

My father, Charles Wright Mills, wanted to come to Europe for years before he made his first trip. He tried to arrange a visiting professorship, explaining his interest this way to Professor Max Horkheimer of Frankfurt:

"I have all my life lived in a country that is only some six or seven generations old, and the longer I work here and the older I get, the more provincial and limited I feel. I want to live in Europe for a while, to put it positively, in order to establish points of comparison." (Mills 1952, 197)

That's a quote from C. Wright Mills: Letters and Autobiographical Writings, which I collected, selected, and co-edited with my half sister, Pamela Mills. All the letters I'll quote today are in that collection.

My father was born and raised in Texas, in a crossroads of cultures, Mexican and American, Catholic and Protestant. His bachelor's degree in sociology and his master's in philosophy were both from the University of Texas at Austin. After he left Texas to go to Madison, Wisconsin, in the north of the U.S., he worked to minimize his southern accent. I think he didn't want his regional accent to distract from the substance of his words. In 1945, he reached the national stage in the United States, when he came to New York City and Columbia University's Bureau of Applied Social Research.

His first attempt to obtain a visiting professorship in Europe did not bear fruit, but fortunately, a different opportunity arose. As he wrote to his friend, Leo Lowenthal, a sociologist from Frankfurt and the Frankfurt School:

"...on the 2Ist of this month [January 1956], by Dutch airline, Mills enters Europe for the first time. I go, as I quite property should, as an amateur mechanic of sports cars and motorcycles. Here's the deal: the importer for BWM and NSU here in New York is a good friend of mine, a fine old Austrian gentleman. He is chartering a plane to take the mechanics of his dealers to the factories for a short service training course, on the care and feeding of little BMWs. He's letting me go along.[...] About two weeks in all. First week in Neckersulm, just above Stuttgart; second week in Munich. I suppose I'll be pretty busy at the factories because honest to God I'd rather hear the roar of an R-69[BMW motorcycle] being bench-tested by a man who knows his motors than see the finest cathedral in the world." (Mills 1956a, 197)

He told his friend, the historian, William Miller, that his trip to Germany for two weeks of training in motorcy- cle maintenance was a huge success, explaining that, by huge success, he meant:

“... I discovered people again. People worth talking to half the night, people with histories so different from mine, and as full of individuality as I ever hope to be. [...] Strangers spent hours teaching me words and pronunciation. [...] During the day I was mostly out at the plant, BMW, and there met technicians and minor managers, with whom at night I often went around. But I was on my own in Munich for four days before the bunch arrived. And that was when I learned the most German. Of course all of this was on the surface, but how good for once to be on the surface and not to get into the tension of analysis!" (Mills I956b, I99f)

My father had studied German at the University of Wisconsin, as part of his $\mathrm{PhD}$ program, but that language course focused on reading and writing. As he freely admitted, he had a tin ear for foreign languages, so learning to speak some German wasn't easy for him.

Many years before his first trip to Europe, he and Hans Gerth worked on From Max Weber: Essays in Sociology. Gerth, a native German speaker, prepared rough translations of the essays by Max Weber in English, and my father edited them energetically to turn them into clear English prose, which Gerth then checked for accuracy against the original German versions.

By the time my father visited the BMW factory in $\mathrm{Mu}-$ nich, his application to the Fulbright Program to work in Europe was approved by academic committees. He was later cleared by the State Department and invited to be a Fulbright lecturer on social psychology at the University of Copenhagen. He had originally applied to do research in England, but he didn't mind when the Fulbright people asked him to lecture in Copenhagen instead. As he explained to Leo and Marjorie Lowenthal "Hell anything is OK, as long as I get there."

My parents and I flew from New York to Copenhagen on May 29, 1956, two months after The Power Elite was first published and one month after my father's promotion to full professor at Columbia. In my father's acknowledgment pages for The Power Elite, he wrote: "My wife, Ruth Harper Mills, as chief researcher and editorial advisor, has shaped much of the book."(Mills 1956d, 364) At the time of our departure for Copenhagen, my father was 39 years old, my mother, Ruth, was 33, and I was a toddler.

Soon after our arrival in Copenhagen, European publishers began to sign up or consider publishing translations of The Power Elite in German, Italian, Japanese, and Danish. My father shared this news with Lewis Coser and Irving Howe at Dissent magazine, and then wrote: 
"I've the feeling the damn thing will get around despite the reviews. Well, we'll see in a year from now. After all, if all these liberal types had acclaimed it, I'd know that I had failed."(Mills I956c, 210)

The Power Elite completed a trilogy about American society and was eventually translated into fifteen languages. In the U.S., it stirred up controversy from all parts of the political spectrum-- right, center, and left. Today there is much less disagreement about its portrait of overlapping elites of power--military, corporate, and political. In 1956, the book was a dissent, surrounded by American celebration of American society.

I think my father's interest in working and living in Europe coincided with a sense that it was time for him to step onto the international stage with his next books. I imagine that he felt a sense of freedom that year, leaving the U.S. soon after obtaining tenure at Columbia.

In a letter from Copenhagen to William Miller, he described his writing life in early February, midway through his year of lecturing at the University of Copenhagen.

"I've not worked much at anything for some months. Now suddenly I began to 'work at' the little book on 'The Sociological Studies,' a quite technical book of I50 pages or so. I think it's time I wrote something about my own kind of sociology and against the current dominant 'schools.' I'm not in any hurry about it, but it comes along. I look forward to telling you about it when I return and, I hope, showing you some manuscript--to establish the right tone--and I think you'll enjoy it as much as I."(Mills 1957a, 227f)

Five or six weeks later, he wrote Bill Miller again, saying he'd been working hard ( 15 hours the previous day) on that little book, which became The Sociological Imagination. He told Miller it was about:

"... the promise, the tasks, the nature of the social sciences (Ch.I). It is at once a 'defense' (without appearing to be such) of the kind of stuff I've done, and a really detailed criticism of 'the methodological inhibition' (Ch. 2) a la Lazarsfeld, and of 'the fetishism of the concept' (Ch. 3) a la Parsons. It also contains a complete, and I believe first-rate rewrite of a neverpublished essay 'On Intellectual Craftsmanship' $(\mathrm{Ch}$. 4) and a brand new version of 'The Political Promise' (Ch. 5), which is set within a neat little view of the role of reason in human affairs, in history. Within it I have also finally been able to state the central role of historical studies in the social sciences as a whole. I

I On the topic of Mills and craftsmanship, I recommend an article by A. Javier Trevino called: "C. Wright Mills as Designer: Personal Practice and Two Public Talks" in: The American Sociologist, Vol. 45, No. 4, December 2014. am very excited about it all, and can't conceive of any sudden shift in my evaluation of it!

I must ask that you not mention any of this to our friends, especially those of Morningside Heights [Columbia University]. I want it to be just one big, dandy surprise: as from a prophet who comes in from a desert."(Mills I957b, 230)

Flash forward 43 years to 2000 , when the book of letters was published by the University of California Press. I organized a public reading called a "Tribute to $C$. Wright Mills" at the New York Public Library, inviting sociologists Todd Gitlin and Norman Birnbaum, the historian, Eric Foner, and others to read passages that they chose from my father's letters or writings--or to reminisce about him if they'd known him personally.

The writer, Dan Wakefield, who had been a student assistant and dear friend of my father's, was the master of ceremonies. My half-brother, Nikolas, travelled from Colorado to give a reading. Robin Swados, the younger son of Harvey Swados (the novelist and writer of short stories and essays) was there to share his memories. Ira Grief, a former student assistant and friend of my father's, came from Boston. Norman Birnbaum flew in from Washington, D.C.. Tom Hayden, the political activist, and Naomi Schneider, from the University of California Press, flew from California to speak at the event. David Amram played piano to accompany most of the spoken program. Amram had played musical backgrounds for readings by Allen Ginsberg, Jack Kerouac, and other Beat writers in the 1950's.

The fortieth anniversary edition of The Sociological Imagination was published the same year as the book of letters--200o. I'm happy to say that Todd Gitlin wrote the new afterword for that anniversary edition. On stage in New York at the tribute, Professor Gitlin read the last few pages of the appendix, "On Intellectual Craftsmanship," as David Amram quietly improvised on piano. Here's the closing paragraph that Todd Gitlin chose to read:

"Do not allow public issues as they are officially formulated, or troubles as they are privately felt, to determine the problems that you take up for study. Above all, do not give up your moral and political autonomy by accepting in somebody else's terms the illiberal practicality of the bureaucratic ethos or the liberal practicality of the moral scatter. Know that many personal troubles cannot be solved merely as troubles, but must be understood in terms of public issues--and in terms of the problems of historymaking. Know that the human meaning of public issues must be revealed by relating them to personal troubles--and to the problems of the individual life. Know that the problems of social science, when ad- 
equately formulated, must include both troubles and issues, both biography and history, and the range of their intricate relations. Within that range the life of the individual and the making of societies occur; and within that range the sociological imagination has its chance to make a difference in the quality of human life in our time." (Mills I959b, 226)

Today a video of the "Tribute to C. Wright Mills" is viewable for free via streaming at the C-Span website.

Let's return to Wright's work in the 1950's on the manuscript that became The Sociological Imagination. He focussed on ideas and approaches, but he made it clear that the grand and unintelligible theory he lambasted could be found in Talcott Parsons's work. And Paul Lazarsfeld, a colleague at Columbia University, was a prominent advocate for what my father called abstracted empiricism and a "withdrawal from the tasks of social sciences." Wright had crossed swords with both Parsons and Lazarsfeld in earlier years, via book reviews of each others' work or, in the case of Lazarsfeld, working together (or trying to) at Columbia's Bureau of Applied Social Research.

Back in 1943, in a letter to Dwight Macdonald, who was launching his magazine, Politics, my father mentioned Talcott Parsons and translations of writings by Max Weber.

"If we could only clear the copyright stuff, we (Gerth and I) could let you have a translation of Max Weber on 'Class and Status' which we've done. [...] It's a section from Wirtschaft und Gesellschaft (Tubinger 1922), if I recall correctly [...] It has never been published in English and is not included in part one of W. und G., which Parsons of Harvard has translated and is now in English press. The son of a bitch translated it so as to take all the guts, the radical guts, out of it, whereas our translation doesn't do that!"(Mills I943, $52^{2}$ )

As for Lazarsfeld, I'll tell you what my father wrote about him from Innsbruck in November 1957 to his friends, Ralph Miliband and Norman Birnbaum, both of whom my father first met during a visit to the London School of Economics. In periods when my dad was taking a break from writing, he often read popular westerns and detective novels. You might notice some influence from those stories in part of this passage.

“... for Io days now I've been doing nothing but write long, two page, single spaced letters with carbons to various people about the Columbia situation. I've had to 'save' two instructors, Litwak and Siegel, and

2 Parsons' project is: The Theory of Social and Economic Organization by Max Weber, edited and with an introduction by Talcott Parsons (1947). Mills's and Gerth's is: From Max Weber: Essays in Sociology (1946). ward off other predatory silliness [...] mounted by Lazarsfeld.

By no means is this sociological brawl at Columbia finished; by no means should it be assumed, as Norman apparently does, that I will lose. On the contrary, this round I think I have won; at least I've strengthened my position considerably and more importantly have broadened to confrontation: administratively by getting it squarely before Dean Barzun and Dean Chamberlain (my college dean); and intellectually by making it turn on something worth fighting about--the cultural crisis of the social studies and the problem of a proper liberal arts education. Until now I have not really fought these people in American sociology; I've ignored them and done my own work; but they've been fooling around behind the scenes and now I declare war: I am going to expose their essential bankruptcy; perhaps with a little circuit of the Ivy League schools; certainly with my book on the social studies, mimeographed drafts of which I shall, if I may, get to you by March.

'I don't hate nobody,' he said. 'I'm just tired of the bullshit.' He said it slowly so they'd all hear it good. Then he swung a couple of chairs into the bar, one following the other like one smash; knocking the bottom off a whiskey bottle, ... [he] moved in close.

Seriously, all that is easy--and can readily be taken, as I do, as a sort of relaxation from serious work." (Mills 1957c, 257)

He went on to describe a house he'd like to build someday in Rockland County, New York, and then closed the letter with an invitation:

"Why don't you all come and spend Christmas in Tyrol?” (Mills I957c, 257)

My father presented early versions of parts of The Sociological Imagination at a seminar in social science at the University of Copenhagen. He continued to work on that manuscript in Innsbruck and later in New York City, writing a friend that he wanted to take his time with it.

In his acknowledgment pages of the finished book, he wrote: "I am very grateful to my friends, William Miller and Harvey Swados, for their continued efforts to help me write clearly." (Mills I959b, 228) He thanked several people from the seminar in Copenhagen for their "penetrating criticisms and kind suggestions" and acknowledged thirty-two other colleagues and friends for their criticisms of drafts in whole or in part.

We left Copenhagen in May 1957, traveling to Salzburg, where my father gave five lectures about politics and culture. Next we came to Innsbruck--my dad leading the way on his motorcycle and my mother driving our VW Bus. 
One of my father's writing projects in Innsbruck was called Contacting the Enemy: Tovarich. I came across that unfinished, unpublished manuscript while looking through his papers for correspondence. Most of that manuscript consists of autobiographical essays, written as letters to an imaginary correspondent, Tovarich, which means friend or comrade in Russian. Tovarich was a dissident and public intellectual like my father, but Tovarich was on the other side of the Iron Curtain. Despite two trips to Russia and one to Poland, my father didn't find someone to be a real Tovarich and contributor to his book, so he settled for writing to an imaginary Tovarich. Wright Mills used his letter-essays to Tovarich to make a political point, writing as one human to another, trying to foster understanding and peace during the height of Cold War hostility between governments. We included those faux letters, along with letters to real people in the collection.

In one letter to Tovarich, my father described driving toward Innsbruck:

"I came over the mountains from Munich to the Inn Valley by a network of back roads; in some stretches they were mere trails. The BMW motorcycle sings in all gears on all gradients; when it's in the woods it's like a mountain goat, a go-anywhere apparatus--not a tool, not a machine--a true apparatus." (Mills I957d, 242)

My parents and I stayed at a camping platz (campground) in Innsbruck until early July when my father and Ralph Miliband took a I6-day-long trip to Poland. My father wanted to interview Polish dissidents, antiSoviet leftists, for a book about intellectuals; and I believe Ralph made some introductions. My mother and I remained at the camping platz until we moved into a gasthaus (an inn).

When my father returned to Innsbruck, our camper van was gone from the camping platz, and my mother and I had left the gasthaus. He couldn't find us, so he went to the police station. He was shocked to learn that my mother was in a psychiatric hospital and I was in a Kinderhaus, an institute for children without parents, now called the Kinderzentrum. My mother had been fine when he left Innsbruck. While my father was on his way back from Poland, the Innsbruck police brought me and my mother to the Bahnhofmission der Caritas (social service charity at the train station), where someone referred my mother to the hospital and me to the Kinderhaus. I had my second birthday a few days before I arrived there.

At the Kinderhaus my father and I met a kindergarten teacher named Gina, who offered to take care of me in her home, an apartment she shared with her grandmother in Innsbruck. My father agreed, hiring her to be my nanny and host. Gina later came to New York where she continued to take care of me for a while.

I was able to see Gina again this week--for the first time since I was three years old--thanks to Veronika Riedl's recent research, which located her for me, here in Innsbruck.

My father spent a few weeks camping in our VW bus in Innsbruck, and then took a room in the Gasthaus Engl, near the Kinderhaus and Innsbruck's Old Town. Later he moved to the Gasthof Hellenstainer, which was then on Andreas-Hofer-Straße, near the university hospital that treated my mother. Eventually he moved to a larger hotel outside Innsbruck.

After our situation had settled a bit, he wrote to a friend saying that my mother's psychiatrist at the Psychiatrisch-Neurologische Klinik Der Universität Innsbruck, Professor Hubert Urban, was the head of his department at the University of Innsbruck. Years later, my mother told me that Dr. Urban was very well known and only treated patients whose cases he found interesting. In the Innsbruck university hospital, she received insulin shock treatments, a common therapy for psychosis at the time.

After my mother left the hospital, she stayed with the Urban family for two months. Dr. Urban lived with his wife and their several children in a home with a spare room set up to host a recovering mental patient--an unusually hospitable version of outpatient care.

About ten years after my family's stay in Innsbruck, my mother began taking lithium medication, then a new treatment for her illness--manic depression, now called bipolar disorder. She took lithium every day for the rest of her long life, as prescribed, and it worked well for her. My mother never needed hospital care for mental illness again. She had an award-winning career as a statistician with the U.S. Census Bureau.

The book of my father's letters and autobiographical writings didn't discuss my mother's hospitalizations because she was alive when it was published, and she preferred to keep her mental health history private--at least in the context of the collection of letters. She died in 2008.

Back to 1957. When my father was settled in the Gasthaus Engl, he wrote friends saying he'd established routines for his writing; his visits to my mother, when visits were allowed; and his visits with me, taking me on picnics or drives around Tyrol. He also hiked or drove his motorcycle to try to relax.

In a letter to Ralph Miliband, he described his writing life in Innsbruck.

"Here I am writing rather impassioned stand-up-allyou-bastards-and begin-to-fight stuff on world politics and intellectuals for two or three or even as many as six hours a day, and then collapsing exhausted. I 
shall remember these days. There ought to be some way to exploit them intellectually." (Mills I957e, 244)

My father had four books underway at the time: a short book on intellectuals; another short book to be called "Politics and Culture," based on the lectures he gave in Salzburg; The Sociological Imagination; and Contacting the Enemy: Tovarich.

My parents had originally planned to return to New York in early September 1957. As September approached, Dr. Urban told my father that my mother wouldn't be ready to end her care in Innsbruck by then, so my father obtained a leave of absence from Columbia University for the fall semester, extending his stay in Tyrol to six months.

Given my family's situation, it's no surprise that one of my father's letters to Tovarich from Innsbruck discussed the topic of personal trouble.

"When you're in trouble, it's as if you're sitting at a huge table with many little piles of notes on it, as if for the chapters of a book. Every day or so the major themes of the book mysteriously shift so that you've got to sort everything out in a different way. Too many decisions all at once, with too many elements you've got no control over; that's what being in trouble is. The decisions and the re-decisions, the tentativeness of anything you do, of all action, gradually wears you down. Questions no longer prod thought; thronging up on you, they clog reason itself.

The process wouldn't be so bad if you were getting somewhere--if it really was a book, for instance. For that's what writing a book is; no matter how complicated all the questions are, no matter how many times you have to decide again, still you come to have more and more control over more and more aspects of it. That's why to write is to get out of trouble, for the trick is to sort it all out in such a way as to be able to work on one part of it at a time, with the whole merely a vague and helpful outline.

To write is to get on top of it all. Writing, at least the thing about writing I'm talking about now, is another name for the creating and the maintaining of a more or less orderly mind of your own, and so a sense of your own identity. When you're writing, you've got a plan, and the changing of it is more or less in your hands; but when you're in trouble, you are overwhelmed by events and issues you have no control over. To be in trouble is to be in the grip of fate but not to be able to get any melodramatic pleasure out of it. To be in trouble is not to be able to plan.

To cope with trouble, you've just got to keep on trying 'to write' -- trying all the time to find an outline of the whole that's stable enough, that's comprehensive enough to permit you to reason about one part of it at a time.
I've only been in personal trouble three or four times, but I'm an old pro at trouble. In trouble I feel like an old man--not a tough old man, but still a survivor. As they say in Austria: 'Bend but don't break.' Or as I say: 'Set up a new file.' Plan 9 has collapsed; set up Plan Io. I used to think old George Mead's slogan, 'We don't know where we're going, but we're on our way,' pretty weak stuff, but it's not. It's the theme song of being in trouble but not being dead."(Mills I957f, 254f)

Today Brazil is in the news because of the murder of Marielle Franco, a human rights activist, feminist, and city councillor in Rio de Janeiro ${ }^{3}$. I'd like to close by reading part of a letter to Tovarich from Rio de Janeiro, Brazil in I959. In this passage, Wright Mills praises Simone de Beauvoir. I think his point about de Beauvoir applies to Marielle Franco as well.

"To be an intellectual human being involves certain choices between grand, although I hope not grandiose, alternatives. The first alternative has to do with everyday life and may be put as follows. Most people relax into the private and everyday life of their milieu. Generally accepting it and their place within in, they take its values as after all the most enjoyable. In the end, the round of family life and the faces of their children, a steady and pleasant job, let us say as a college professor, and later a nice home, an article published every three years and maybe a textbook to quilt together--isn't that about all there is in it? And after all, isn't that a pretty good life? Perhaps most people today would say at once, yes, it must be.

Here is the second alternative, which can be put in the form of questions: Shall I build my life around projects that transcend the everyday and private life? Generally rejecting as paramount the values of that life and my place within it, shall I come into tension with it whenever necessary? Shall I come to see myself as not only an ordinary man but also as in some way representative of the discourse of reason?

One key word here is 'project,' which I take from Simone de Beauvoir, an admirable woman who has chosen the second alternative, and whom you ought to read, especially if you are a woman or know any women. Another key is 'standard,' by which I mean the demands that you formulate and accept and make upon yourself. It is not so much that you live for ideas, it is that you really cannot live without them-although of course you can exist. But you are not in involuntary servitude to the powers of the commonplace and the terrible domination of the everyday.

3 'In Brazil, I,ooo Protest Murder of Rio de Janeiro Councilwoman' by the New York Times ( The New York Times, March I8, 20I8). 
Most people do not go after things which are out of their reach, but the intellectual, the artist, and the scientist do just that. To do so is a normal feature of their working lives. They look at their paintings, they think of their books, they examine again the formula, and they know that it is not good enough and perhaps never will be.

To be disgruntled with the way the world is going is not necessarily to be a disgruntled person. To be uneasy about the world is not necessarily to be uneasy with yourself. Although a good deal of your experience is perhaps necessarily estranged, the capacity for life experience need not be expropriated. It is quite possible to be suitably isolated and therefore not alienated; it is possible to live in an overdeveloped society but not be an underdeveloped person." (Mills I959a, 277f)

He goes on to discuss the importance of carefully choosing escapes from routines in order to learn about oneself and the world--and next, the international character of intellectual life.

"You and I, Tovarich, we are students, writers, and readers; we belong to something that's bigger than any government; we owe loyalty, if you want, to something higher than any one state. Political loyalties are conditional upon our reasoning, and such loyalties are not circumscribed by national boundaries. This is a very important point for our attempt to communicate. Intellectual life, and so the working life of any intellectual, is not confined to any one nation. The minds of intellectuals have been formed by an essentially international process, and their work is essentially an international traffic.

The internationalism of the mind and sensibilities is not an abstract internationalism. Nor is it inaccessible. It is available in the bookstore on the corner, and the library downtown; it is as solid as the feeling set up by the look of a steel beam, as specific as the grace of a bamboo shoot, as general as the idea of nature or humanity. The internationalism of the mind and sensibilities is inherent in the intellectual's principle that all belief ought to be conditional upon the individual's reasoning, and that all his or her sensibilities and preferences of moral and aesthetic value ought to be products of conscious self-cultivation. There is no other meaning of the free use of the human mind, of the genuine liberation of the self." (Mills I959a, 279)

Danke.

\section{References}

Mills, C. Wright (1943), Letter to Dwight Macdonald, in: Mills, Kathryn [with Pamela Mills] (ed.), 5I-53.

Mills, C. Wright (1952), Letter to Professor Max Horkheimer, in: Mills, Kathryn [with Pamela Mills] (ed.), 197 .

Mills, C. Wright (1956a), Letter to Leo and Marjorie Lowenthal, in: Mills, Kathryn [with Pamela Mills] (ed.), 197-198.

Mills, C. Wright (1956b), Letter to William Miller, in: Mills, Kathryn [with Pamela Mills] (ed.), 199-200.

Mills, C. Wright (1956c), Letter to Lewis A. Coser and Irving Howe (Dissent magazine), in: Mills, Kathryn [with Pamela Mills] (ed.), 209-2IO.

Mills, C. Wright (1956d), The Power Elite, New York: Oxford University Press.

Mills, C. Wright(1957a), Letter to William Miller, in: Mills, Kathryn [with Pamela Mills] (ed.), 227-229.

Mills, C. Wright (1957b), Letter to William Miller, in: Mills, Kathryn [with Pamela Mills] (ed.), 229-23I.

Mills, C. Wright (1957c), Letter to Ralph Miliband and Norman Birnbaum, in: Mills, Kathryn [with Pamela Mills], 257-258.

Mills, C. Wright (1957d), Letter to Tovarich, in: Mills, Kathryn [with Pamela Mills] (ed.), 24I-243.

Mills, C. Wright (1957e), Letter to Ralph Miliband, in: Mills, Kathryn [with Pamela Mills] (ed.), 244-245.

Mills, C. Wright (1957f), Letter to Tovarich, in: Mills, Kathryn [with Pamela Mills] (ed.), 253-255.

Mills, C. Wright (1959a), Letter to Tovarich, in: Mills, Kathryn [with Pamela Mills] (ed.), 276-28I.

Mills, C. Wright (1959b), The Sociological Imagination, New York: Oxford University Press.

Mills, Kathryn [with Pamela Mills] (ed.) (200o), C. Wright Mills: Letters and Autobiographical Writings, Berkeley/Los Angeles/London: University of California Press. Selections from letters and writings by C. Wright Mills reprinted with permission.

\section{Author}

Kathryn (Kate) Mills is C. Wright Mills' daughter with Ruth Mills, the statistician who worked with him on White Collar and The Power Elite. Kate collected, selected and co-edited C. Wright Mills: Letters and Autobiographical Writings (edited with Pamela Mills, University of California Press, 200o). An essay collection entitled $C$. Wright Mills and the Sociological Imagination (edited by John Scott and Ann Nilsen, Edward Elgar Publishing Limited, 2013) includes a foreword and an essay by Kate Mills. She graduated from Hampshire College with a B.A. in political economics. For 35 years, Kate worked for Houghton Mifflin Harcourt Publishing Company in Boston, Mas- 
sachusetts, U.S.A, most recently as Vice President, Trade Contracts. Her personal essay, "Up in Smoke," will be published in a forthcoming issue of The Massachusetts Review. She is working on a memoir.

Kathryn (Kate) Mills ist die Tochter von C. Wright Mills und Ruth Mills, die Statistikerin, welche mit ihm an White Collar und The Power Elite arbeitete. Kate sammelte, wählte aus und war Mitherausgeberin von $C$. Wright Mills: Letters and Autobiographical Writings (herausgegeben mit Pamela Mills, University of California Press, 2000). Eine Essay-Sammlung mit dem Titel C. Wright Mills and the Sociological Imagination (herausgegeben von John Scott und Ann Nilsen, Edward Elgar Publishing Limited, 20I3) beinhaltet ein Vorwort und ein Essay von Kate Mills. Sie erwarb ihren BA in Politischer Ökonomie am Hampshire College. Über 35 Jahre hinweg arbeitete sie für Houghton Mifflin Harcourt Publishing Company in Boston, Massachusetts, USA, zuletzt als Vizepräsidentin für Handelsverträge. Ihr autobiographisches Essay "Up in Smoke" wird in einer kommenden Ausgabe von The Massachusetts Review erscheinen. Sie schreibt derzeit an ihren Memoiren. 